\title{
Cyclic Adenosine Monophosphate-stimulated Bicarbonate Secretion in Rabbit Cortical Collecting Tubules
}

Victor L. Schuster

With the technical assistance of Kart M. Kjer

Laboratory of Epithelial Transport, Department of Internal Medicine, University of Iowa, and

Veterans Administration Medical Center, Iowa City, Iowa 52242

\section{Abstract}

We studied the effects of cyclic AMP (cAMP) on $\mathrm{HCO}_{3}^{-}$ transport by rabbit cortical collecting tubules perfused in vitro. Net $\mathrm{HCO}_{3}^{-}$secretion was observed in tubules from $\mathrm{NaHCO}_{3}^{-}$ loaded rabbits. 8-Bromo-cAMP-stimulated net $\mathrm{HCO}_{3}^{-}$secretion, whereas secretion fell with time in control tubules. Both isoproterenol and vasopressin (ADH) are known to stimulate adenylate cyclase in this epithelium; however, only isoproterenol stimulated net $\mathrm{HCO}_{3}^{-}$secretion.

The mechanism of cAMP-stimulated $\mathrm{HCO}_{3}^{-}$secretion was examined. If both $\mathrm{HCO}_{3}^{-}$and $\mathrm{H}^{+}$secretion were to occur simultaneously in tubules exhibiting net $\mathrm{HCO}_{3}^{-}$secretion, cAMP might increase the net $\mathrm{HCO}_{3}^{-}$secretory rate by inhibiting $\mathrm{H}^{+}$secretion, by stimulating $\mathrm{HCO}_{3}^{-}$secretion, or both. These possibilities were examined using basolateral addition of the disulfonic stilbene $\left(4,4^{\prime}\right.$-diisothiocyanostilbene-2,2'-disulfonate (DIDS). In acidifying tubules from $\mathrm{NH}_{4} \mathrm{Cl}$-loaded rabbits, DIDS eliminated $\mathrm{HCO}_{3}^{-}$reabsorption, a result consistent with known effects of DIDS as an inhibitor of $\mathrm{H}^{+}$secretion. In contrast, cAMP left acidification $\left(\mathrm{H}^{+}\right.$secretion) intact. DIDS applied to $\mathrm{HCO}_{3}^{-}$secretory tubules failed to increase the $\mathrm{HCO}_{3}^{-}$secretory rate, indicating minimal $\mathrm{H}^{+}$secretion in $\mathrm{HCO}_{3}^{-}$-secreting tubules. Thus, inhibition of $\mathrm{H}^{+}$secretion by cAMP could not account for the CAMP-induced stimulation of net $\mathrm{HCO}_{3}^{-}$secretion.

cAMP-stimulated $\mathrm{HCO}_{3}^{-}$secretion was reversibly eliminated by $0 \mathrm{Cl}$ perfusate, whereas luminal DIDS had no effect. Bath amiloride (1 $\mathrm{mM}$ ) failed to eliminate cAMP-stimulated $\mathrm{HCO}_{3}^{-}$secretion when bath $\left[\mathrm{Na}^{+}\right]$was $145 \mathrm{mM}$ or $5 \mathrm{mM}$. cAMP depolarized the transepithelial voltage. The collected fluid $\left[\mathrm{HCO}_{3}^{-}\right]$after $\mathrm{cAMP}$ could be accounted for by electrical driving forces, suggesting that CAMP stimulates passive $\mathrm{HCO}_{3}^{-}$secretion. However, cAMP did not alter $\mathrm{HCO}_{3}^{-}$permeability measured under conditions expected to inhibit transcellular $\mathrm{HCO}_{3}^{-}$movement (0 Cl${ }^{-}$solutions and bath DIDS). This measured $\mathrm{HCO}_{3}^{-}$permeability was not high enough to account, by passive diffusion, for the $\mathrm{HCO}_{3}^{-}$fluxes observed in $\mathrm{Cl}^{-}$-containing solutions.

We conclude the following: 1) cAMP increased net $\mathrm{HCO}_{3}^{-}$secretion by stimulating $\mathrm{HCO}_{3}^{-}$secretion and not by

A portion of this work was presented at the 17th Annual Meeting of the American Society of Nephrology, Washington, DC, and has appeared in abstract form. 1985. Kidney Int. 27:288.

Received for publication 10 December 1984 and in revised form 18 February 1985.

J. Clin. Invest.

(c) The American Society for Clinical Investigation, Inc.

0021-9738/85/06/2056/09 \$1.00

Volume 75, June 1985, 2056-2064 inhibiting $\mathrm{H}^{+}$secretion; 2) this $\mathrm{HCO}_{3}^{-}$secretion may have occurred by $\mathrm{Cl}-\mathrm{HCO}_{3}^{-}$exchange; 3) $\mathrm{Na}^{+}-\mathrm{H}^{+}$exchange appeared not to play a role in basolateral $\mathrm{H}^{+}$extrusion under these conditions; and 4) the stimulation of $\mathrm{HCO}_{3}^{-}$secretion by isoproterenol, but not ADH, suggests the existence of separate cell cAMP pools or cellular heterogeneity in this cAMP response.

\section{Introduction}

Net $\mathrm{HCO}_{3}^{-}$secretion has been described in cortical collecting tubules dissected from alkali-loaded rats and rabbits (1-4), but little is known about the hormonal control of this process. Although initial studies by Knepper et al. suggested that chronic mineralocorticoid administration stimulates $\mathrm{HCO}_{3}^{-}$ secretion by the cortical collecting tubule (5), subsequent investigation has shown that this stimulation is secondary to the accompanying metabolic alkalosis rather than a direct hormonal affect on $\mathrm{HCO}_{3}^{-}$transport (6). In contrast, cyclic nucleotides directly stimulate $\mathrm{HCO}_{3}^{-}$secretion in a number of epithelia including salivary gland (7), small intestine (8), and choroid plexus (9). The present studies on rabbit cortical collecting tubules have focused on cyclic AMP (cAMP) and two hormones known to stimulate adenylate cyclase in this nephron segment, namely, vasopressin $(\mathrm{ADH})^{1}$ and isoproterenol (10). Our experiments demonstrate that cAMP stimulated $\mathrm{HCO}_{3}^{-}$secretion and address the mechanism of this stimulation.

\section{Methods}

General microperfusion methods. In vitro microperfusion of cortical collecting tubules was performed as previously described (11). In studies examining $\mathrm{HCO}_{3}^{-}$secretion, tubules were dissected from rabbits given normal rabbit chow ad lib. and drinking water consisting of $0.075 \mathrm{M} \mathrm{NaHCO}_{3}$ and $0.1 \mathrm{M}$ glucose for 3-14 $\mathrm{d}$ before study. In studies examining acidification $\left(\mathrm{HCO}_{3}^{-}\right.$reabsorption), tubules were dissected from rabbits starved for $\mathbf{3} \mathbf{d}$ and given a drinking solution of $0.075 \mathrm{M} \mathrm{NH}_{4} \mathrm{Cl}$ and $0.1 \mathrm{M}$ glucose for 3-7 $\mathrm{d}$ before study. Female New Zealand white rabbits from either of these two groups were killed by decapitation, the left kidney was quickly removed, 1-2-mm coronal slices were cut, and dissection was performed at $4^{\circ} \mathrm{C}$. Tubules were transferred to a thermostatically controlled chamber of $1 \mathrm{ml}$ vol and were connected to perfusing and holding pipettes. Continuous bath exchange at $\geq 0.6 \mathrm{ml} / \mathrm{min}$ was begun, and the temperature of the chamber was warmed to $38^{\circ} \mathrm{C}$. After a 60 -min equilibration period, collections were begun.

Collected fluid spontaneously filled a calibrated volume pipette (CVP) under water-equilibrated mineral oil. CVP volumes ranged from 23-33 nl. In all periods, 3-4 collections for $\mathrm{HCO}_{3}^{-}$concentration (total

1. Abbreviations used in this paper: $\mathrm{ADH}$, vasopressin; CVP, calibrated volume pipette; DIDS, 4,4'-diisothiocyanostilbene-2,2'-disulfonate; $J_{v}$, net volume flux; $\mathrm{tCO}_{2}$, total $\mathrm{CO}_{2}$; TMA, tetramethylammonium; $\mathrm{V}_{\mathrm{T}}$, transepithelial voltage. 
$\mathrm{CO}_{2}\left[\mathrm{tCO}_{2}\right]$, see below) were bracketed by 2-3 collections for net volume flux $\left(J_{v}\right)$. At the end of each experiment, the perfusate was calibrated as follows. The perfusion pipette was advanced into a second pipette ("calibrating pipette") containing Sylgard (Dow Corning Corp., Midland, MI) backed by water-equilibrated mineral oil. Perfusate was then forced between the Sylgard and oil. The CVP was filled at $38^{\circ} \mathrm{C}$ and analyzed for either $\left[{ }^{3} \mathrm{H}\right]$ inulin counts or $\mathrm{HCO}_{3}^{-}$concentration, each of which was measured in triplicate at least.

Transepithelial voltage $\left(V_{T}\right)$ was measured by connecting a Ringeragarose bridge to the perfusion pipette and to a calomel electrode. A similar bridge in the bath, also connected to a calomel electrode, completed the circuit. $\mathrm{V}_{\mathrm{T}}(\mathrm{mV})$ was measured with an electrometer (Keithley Instruments, Inc., Cleveland, $\mathrm{OH}$ ) and continuously recorded on a strip-chart recorder. Voltages at the perfusion pipette were reported referenced to the bath as ground.

All tubules were perfused at or near $1 \mathrm{nl} / \mathrm{mm}$ tubule length per min. The mean paired difference between all control period and al experimental period perfusion rates was $0.015 \pm 0.03(\mathrm{SD}) \mathrm{nl} / \mathrm{mm}$ tubule length per min.

Solutions. The composition of perfusing and bathing solutions is shown in Table I. Solutions A, C, and E were used as perfusates, and solutions $\mathrm{B}, \mathrm{D}$, and $\mathrm{F}$ as baths. The combination $\mathrm{A}$ and $\mathrm{B}$ was used in most protocols; solutions $C$ and $D$ were used to determine passive $\mathrm{HCO}_{3}^{-}$permeability; solution $\mathrm{E}$ was used for luminal $\mathrm{Cl}$ removal; and solution $\mathrm{F}$ was used for some of the bath amiloride studies. All solutions were gassed with $95 \% \mathrm{O}_{2} / 5 \% \mathrm{CO}_{2}$. Tetramethylammonium (TMA) was generated from TMA-OH and $\mathrm{CO}_{2} \cdot\left[{ }^{3} \mathrm{H}\right]$ Inulin (New England Nuclear, Boston, MA), exhaustively dialyzed to remove fragments $<3,000 \mathrm{~mol} w \mathrm{w}$, was added to perfusates as a volume marker. Preliminary experiments showed that tubule viability was somewhat higher in albumin-containing baths as opposed to Ringers alone, and that the responses to hormones and inhibitors were qualitatively the same with or without albumin. Therefore, bovine serum albumin (BSA) (CRG-7; Armour Pharmaceutical Co., Tarrytown, NY) was used in all baths except the $0 \mathrm{Cl}$ bath (solution D).

Microcalorimetry. In all of the present studies except those examining $\mathrm{HCO}_{3}^{-}$permeability, bicarbonate concentrations of perfused and collected fluid were operationally defined as the $\mathrm{tCO}_{2}$, measured by microcalorimetry (Picapnotherm; World Precision Instruments, Inc., New Haven, CT) with the realization that this approximation systematically overestimates $\left[\mathrm{HCO}_{3}^{-}\right]$by the amount of dissolved $\mathrm{CO}_{2}$, which is $1.2 \mathrm{mM}$ at a constant $\mathrm{PCO}_{2}$ of $40 \mathrm{mmHg}$. With regard to $\mathrm{tCO}_{2}$ measurements, we were able to consistently exceed the manufacturer's

Table I. Composition of Perfusing and Bathing Solutions

\begin{tabular}{lcccccc}
\hline Solution & A & B & C & D & E & F \\
\hline $\mathrm{Na}^{+}$ & 145 & 145 & 145 & 145 & 145 & 5 \\
$\mathrm{~K}^{+}$ & 5 & 5 & 5 & 5 & 5 & 5 \\
$\mathrm{Cl}^{-}$ & 115 & 115 & 0 & 0 & 0 & 115 \\
$\mathrm{HCO}_{3}^{-}$ & 25 & 25 & 5 & 25 & 25 & 25 \\
$\mathrm{Ca}^{++}$ & 1.8 & 1.8 & 1.8 & 1.8 & 1.8 & 1.8 \\
$\mathrm{Mg}^{++}$ & 1.0 & 1.0 & 1.0 & 1.0 & 1.0 & 1.0 \\
$\mathrm{PO}_{4}^{-}$ & 2.3 & 2.3 & 0 & 2.3 & 2.3 & 2.3 \\
SO $^{-}$ & 1.0 & 1.0 & 1.0 & 1.0 & 1.0 & 1.0 \\
Acetate & 10 & 10 & 0 & 0 & 10 & 10 \\
Glucose & 8 & 8 & 13 & 8 & 8 & 8 \\
Alanine & 5 & 5 & 5 & 5 & 5 & 5 \\
Gluconate & 0 & 0 & 135 & 115 & 115 & 0 \\
TMA & 0 & 0 & 0 & 0 & 0 & 140 \\
BSA & 0 & 1 & 0 & 0 & 0 & 1
\end{tabular}

Concentrations in millimolars except BSA which is in grams per deciliters. stated sensitivity by modifying the $\mathrm{LiOH}$ crystal as follows. Relatively large anhydrous LiOH crystals (\#44102, $-4 \pm 14$ mesh; Alfa Products, Morton Thiokol Inc., Danvers, MA) were stored in desiccating Drierite (W. A. Hammond Drierite Co., Xenia, $\mathrm{OH}$ ). Just before use, crystals were heated to $200^{\circ} \mathrm{C}$ for $10 \mathrm{~min}$, and then hand-carved under a dissecting microscope with a razor blade and forceps into a thin wafer $1 \mathrm{~mm}$ square and $\sim 1 / 3-1 / 2 \mathrm{~mm}$ thick. One surface of this wafer was chiseled with forceps so that it was concave, and the crystal was mounted with this concave surface toward the thermistor bead. This method consistently yielded signals of $\geq 25$ integrator units $/ \mathrm{pmol} \mathrm{tCO}_{2}$, and water blanks of $\leq 10$ integrator units/nl of sample.

Calculations. Net volume flux was calculated from the equation $J_{v}$ $=\left(V_{\mathrm{i}}-V_{0}\right) / L . V_{0}$ is the collection rate (nanoliters per minute) measured directly; $V_{\mathrm{i}}$ is the perfusion rate (nanoliters per minute) calculated from $V_{\mathrm{i}}=V_{0}\left(\mathrm{cpm}_{0} / \mathrm{cpm}_{\mathrm{i}}\right)$, where $\mathrm{cpm}_{0}$ and $\mathrm{cpm}_{\mathrm{i}}$ are perfused and collected fluid ${ }^{3} \mathrm{H}$ counts per minute per nanoliter; and $L$ is tubule length measured by eyepiece micrometer. Net $\mathrm{HCO}_{3}^{-}$flux, $J_{\mathrm{HCO}_{3}^{-}}$ (picomoles per millimeter per minute), was calculated from the following equation: $J_{\mathrm{HCO}_{3}^{-}}=\left[\left(V_{\mathrm{i}}\right)\left(\mathrm{tCO}_{2}\right)_{\text {in }}-\left(V_{0}\right)\left(\mathrm{tCO}_{2}\right)_{\text {out }}\right] / L$, where $\left(\mathrm{tCO}_{2}\right)_{\text {in }}$ and $\left(\mathrm{tCO}_{2}\right)_{\text {out }}$ are perfused and collected fluid $\mathrm{tCO}_{2}$ concentrations (mM), and $V_{\mathrm{i}}, V_{0}$, and $L$ have their aforestated meanings. Since determinations of $\mathrm{tCO}_{2}$ were alternated with $J_{\mathrm{v}}$ measurements, the $V_{\mathrm{i}}$ term for each $J_{\mathrm{HCO}_{3}^{-}}$was calculated from the measured $V_{0}$ and the average $J_{\mathrm{v}}$ for that experimental period. By convention, negative values for $J_{\mathrm{HCO}_{3}^{-}}$signify net $\mathrm{HCO}_{3}^{-}$secretion and positive values net reabsorption. Tubules were excluded if the $J_{v}$ exceeded $\pm 0.1 \mathrm{nl} / \mathrm{mm}$ per $\mathrm{min}$ in the absence of ADH or cAMP, i.e., if there was a significant inulin leak.

The $V_{T}$ required to account for the collected fluid $\left[\mathrm{HCO}_{3}^{-}\right]$by passive diffusion along electrical gradients was calculated from the Nernst equation (12):

$E_{\mathrm{HCO}_{3}^{-}}(\mathrm{mV})=\frac{-R T}{F} \ln \frac{\left[\mathrm{HCO}_{3}^{-}\right]_{\text {bath }}}{\left[\mathrm{HCO}_{3}^{-}\right]_{\text {out }}}$,

where $R$ is the gas constant, $T$ is degrees Kelvin, $F$ is the Faraday constant, and $\left[\mathrm{HCO}_{3}^{-}\right]_{\text {bath }}$ and $\left[\mathrm{HCO}_{3}^{-}\right]_{\text {out }}$ are bath and collected fluid $\mathrm{tCO}_{2}$ concentrations (mM), respectively, measured by microcalorimetry.

The apparent $\mathrm{HCO}_{3}^{-}$permeability was calculated from the increase in luminal $\left[\mathrm{HCO}_{3}^{-}\right]$above a 5 -mM perfusate value using the GoldmanHodgkin-Katz equation (12):

$P_{\mathrm{HCO}_{3}}=\frac{J_{\mathrm{HCO}_{3}}}{(2 \pi r)(\xi)\left\{\frac{C_{\mathrm{b}}-\frac{C_{\mathrm{i}}^{1}+C_{0}^{1}}{2} e^{-\xi}}{1-e^{-\xi}}\right\}}$,

where $\xi=F \mathrm{~V}_{\mathrm{T}} / R T, r$ is tubule radius (assumed $=10 \mu \mathrm{m}$ ), $J_{\mathrm{HCO}_{3}}$ is net $\mathrm{HCO}_{3}^{-}$flux, $C_{\mathrm{b}}$ is bath $\mathrm{HCO}_{3}^{-}$concentration, $C_{\mathrm{i}}^{-}$is perfusate $\mathrm{HCO}_{3}^{-}$concentration, and $C_{0}^{\prime}$ is collected fluid $\mathrm{HCO}_{3}^{-}$concentration, all determined by microcalorimetry; $\mathrm{V}_{\mathrm{T}}$ is corrected for liquid junction potentials; and $F, R$, and $T$ are as described above. Because these experiments involved measuring collected fluid $\mathrm{tCO}_{2}$ concentrations of around 5-8 mM, the $1.2 \mathrm{mM}$ contribution of dissolved $\mathrm{CO}_{2}$ would contribute proportionately more to the estimation of true $\left[\mathrm{HCO}_{3}^{-}\right]$ than in experiments with collected fluid $\left[\mathrm{HCO}_{3}^{-}\right]$of $25-40 \mathrm{mM}$. Therefore, in these $\mathrm{HCO}_{3}^{-}$permeability studies, $1.2 \mathrm{mM}$ was subtracted from all $\mathrm{tCO}_{2}$ concentrations to more closely estimate true $\left[\mathrm{HCO}_{3}^{-}\right]$.

Reagents. Arginine ADH, 8-bromo-cAMP, isoproterenol, Na, K, and $\mathrm{Ca}$ gluconate, TMA-Cl, and TMA-OH were purchased from Sigma Chemical Co., (St. Louis, MO). Amiloride was a kind gift of the Merck Sharp \& Dohme Div., West Point, PA. 4,4'-Diisothiocyanostilbene-2,2'-disulfonate (DIDS) was purchased from Pierce Chemical Co. (Rockford, IL).

Acid-base parameters. In most rabbits, urine $\mathrm{pH}$ and whole blood pH (drawn from an ear vein into a heparinized syringe) were measured at $38^{\circ} \mathrm{C}$ under oil by $\mathrm{pH}$ electrode. Blood was collected at decapitation, allowed to clot, centrifuged, and serum $\left[\mathrm{HCO}_{3}^{-}\right]$measured by microcalorimetry. 
Statistics. The values from three to four collections per experimental period were averaged to yield a single value for that tubule. Thus, $n$ refers to number of tubules. The $t$ test was used for paired and unpaired comparisons as appropriate. Differences were considered significant if $P<0.05$. Mean values are reported as \pm SE unless otherwise indicated.

\section{Results}

Systemic acid-base parameters. The results of urine and blood $\mathrm{pH}$ and serum $\left[\mathrm{HCO}_{3}^{-}\right]$measurements on $\mathrm{HCO}_{3}^{-}$-loaded and $\mathrm{NH}_{4} \mathrm{Cl}$-loaded, starved rabbits are shown in Table II. There were highly significant differences in all three parameters between the two groups.

cAMP, $\mathrm{ADH}$, and isoproterenol effects on net $\mathrm{HCO}_{3}^{-}$secretion. In this group of experiments, net $\mathrm{HCO}_{3}^{-}$secretory rates were measured in tubules harvested from $\mathrm{HCO}_{3}^{-}$-loaded rabbits; perfusate was solution $\mathrm{A}$, and bath was solution $\mathrm{B}$. Fig. 1 shows the results of time control experiments. The $\mathrm{HCO}_{3}^{-}$ secretory rate fell with time (paired $\Delta=+3.84 \pm 1.09 \mathrm{pmol} /$ $\mathrm{mm}$ per $\min , P<0.02)$. The $\mathrm{V}_{\mathrm{T}}(-8.3 \pm 2.4 \mathrm{mV})$ did not significantly change with time (paired $\Delta=-1.5 \pm 1.6 \mathrm{mV}$ ).

In contrast to these spontaneous time-dependent changes, 8-bromo-cAMP ( $0.1 \mathrm{mM})$ added to the bath (Fig. 2$)$ stimulated net $\mathrm{HCO}_{3}^{-}$secretion (paired $\Delta=-4.53 \pm 1.29 \mathrm{pmol} / \mathrm{mm}$ per min, $P<0.025$ by paired analysis, $P<0.001$ by unpaired analysis to time controls). Associated with this change in $\mathrm{HCO}_{3}^{-}$flux, cAMP depolarized $\mathrm{V}_{\mathrm{T}}$ from $-21.8 \pm 4.7$ to $+12.8 \pm 5.7 \mathrm{mV}$ (paired $\Delta=+34.6 \pm 7.9 \mathrm{mV}, P<0.02$ ). Perfusion rates in control and experimental periods were not significantly different (paired $\Delta=0.046 \pm 0.019 \mathrm{nl} / \mathrm{mm}$ length per min).

Both $\mathrm{ADH}$ and isoproterenol stimulate adenylate cyclase in the rabbit cortical collecting tubule (10). Therefore, we examined the effects of these two hormones on $\mathrm{HCO}_{3}^{-}$secretion. Fig. 3 shows the effects of $100 \mu \mathrm{U} / \mathrm{ml}$ bath $\mathrm{ADH}$ on $\mathrm{HCO}_{3}^{-}$ secretion. $J_{\mathrm{HCO}_{3}^{-}}$fell with $\mathrm{ADH}$ (paired $\Delta=+4.29 \pm 1.09 \mathrm{pmol} /$ $\mathrm{mm}$ per $\mathrm{min}$ ), a change that is not significantly different from that observed in time-control experiments (Fig. 1). ADH depolarized $\mathrm{V}_{\mathrm{T}}$ from $-24.8 \pm 6.7$ to $-16.8 \pm 3.2 \mathrm{mV}$ (paired $\Delta$ $=+8.0 \pm 6.4 \mathrm{mV}, \mathrm{NS}$ ).

In contrast, as shown in Fig. 4 addition of isoproterenol $\left(10^{-6} \mathrm{M}\right)$ to the bath resulted in a stimulation of $\mathrm{HCO}_{3}^{-}$ secretion in eight of nine tubules (paired $\Delta=-1.89 \pm 0.89$ $\mathrm{pmol} / \mathrm{mm}$ per min, $P=0.07)$. When compared with time controls, the change in $\mathrm{HCO}_{3}^{-}$secretion induced by isoproterenol was highly significant $(P<0.005)$. Perfusion rates in the two periods were not significantly different (paired $\Delta$ $=0.003 \pm 0.008 \mathrm{nl} / \mathrm{mm}$ length per $\mathrm{min}$ ). Isoproterenol, like cAMP, depolarized $\mathrm{V}_{\mathrm{T}}$ from $-24.8 \pm 5.6$ to $-3.8 \pm 5.0 \mathrm{mV}$ (paired $\Delta=+21.2 \pm 4.2 \mathrm{mV}, P<0.001$ ).

Table II. Systemic Acid-Base Parameters

\begin{tabular}{llll}
\hline & Urine $\mathrm{pH}$ & Blood pH & Serum $\left[\mathrm{HCO}_{3}^{-}\right]$ \\
\hline $\begin{array}{c}\mathrm{HCO}_{3}^{-} \text {-loaded, } \\
\text { fed }(n)\end{array}$ & $8.22 \pm 0.04(55)$ & $7.56 \pm 0.01 \quad(54)$ & $24.7 \pm 0.6 \quad(38)$ \\
$\begin{array}{c}\mathrm{NH}{ }_{4} \mathrm{Cl} \text {-loaded, } \\
\text { starved }(n)\end{array}$ & $5.16 \pm 0.45^{*}(8)$ & $7.35 \pm 0.04^{*}(9)$ & $12.6 \pm 2.2^{*}(7)$
\end{tabular}

* Significantly different from $\mathrm{HCO}_{3}^{-}$-loaded group at $P<0.0001$.

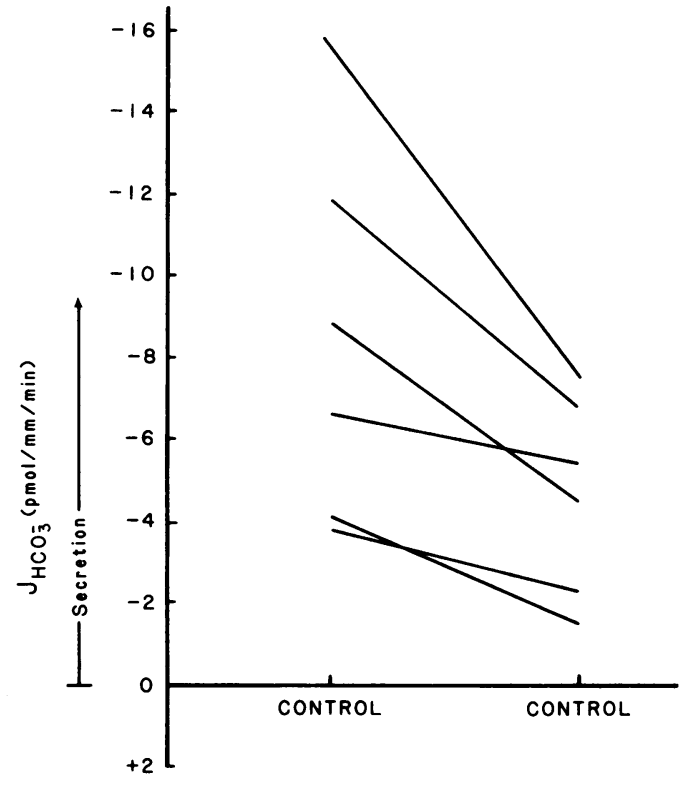

Figure 1. Rate of $\mathrm{HCO}_{3}^{-}$secretion in cortical collecting tubules dissected from $\mathrm{HCO}_{3}^{-}$-loaded rabbits as a function of time perfused in vitro. The two periods were separated by $30 \mathrm{~min}$. Perfusate and bath contained $25 \mathrm{mM} \mathrm{HCO}_{3}^{-}$. Mean bicarbonate fluxes for the two periods are $-8.48 \pm 1.92$ and $-4.65 \pm 0.98 \mathrm{pmol} / \mathrm{mm}$ per $\mathrm{min}$.

Neither the change in $V_{T}$ produced by cAMP nor that produced by isoproterenol showed a significant correlation with the baseline values of $\mathrm{V}_{\mathrm{T}}(r=-0.69$ and -0.50 , respectively; NS). Likewise, the changes in $\mathrm{HCO}_{3}^{-}$secretion produced by cAMP and isoproterenol did not correlate with the changes

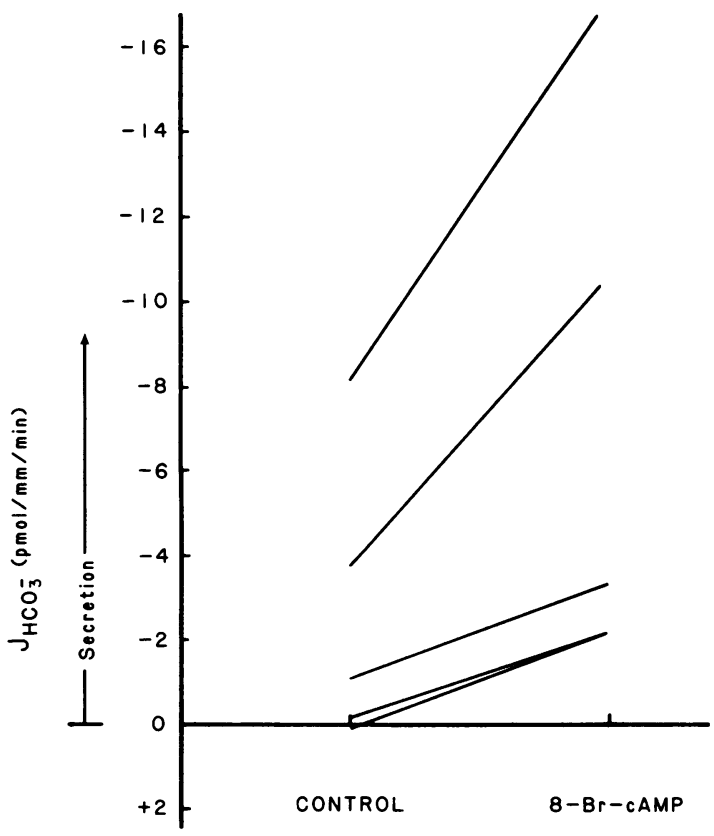

Figure 2. Effect of 8-bromo-cAMP (8-Br-cAMP) $(0.1 \mathrm{mM})$ added to the bath on $\mathrm{HCO}_{3}^{-}$secretion. Conditions are as in Fig. 1. Mean $\mathrm{HCO}_{3}^{-}$secretory rates for the control and 8-Br-cAMP periods are $-2.49 \pm 1.58$ and $-6.96 \pm 2.88 \mathrm{pmol} / \mathrm{mm}$ per min, respectively. The increase is significantly different from time controls in Fig. 1 ( $P$ $<0.001$ ). 


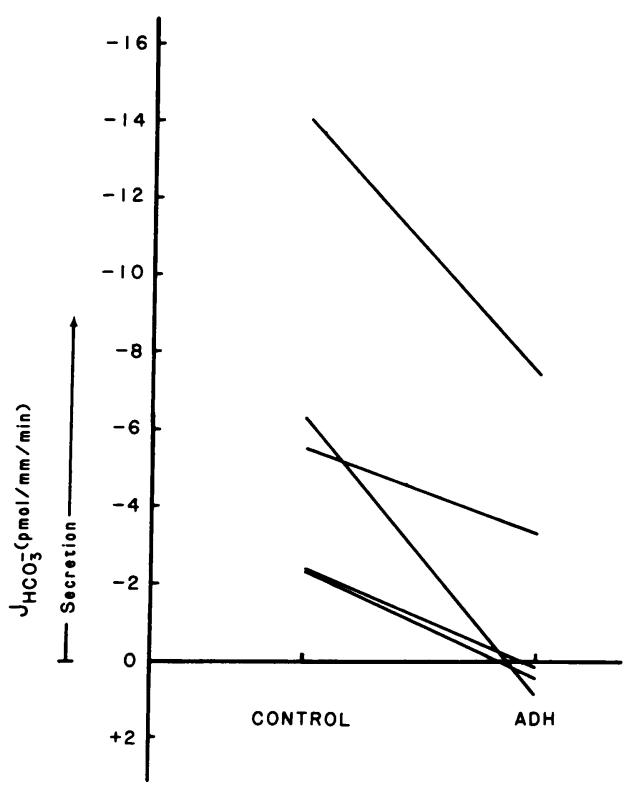

Figure 3. Effect of bath ADH $(100 \mu \mathrm{U} / \mathrm{ml})$ on $\mathrm{HCO}_{3}^{-}$secretion. Conditions as per Fig. 1. Mean $\mathrm{HCO}_{3}^{-}$secretory rates for the control and ADH periods are $-6.10 \pm 2.13$ and $-1.81 \pm 1.57 \mathrm{pmol} / \mathrm{mm}$ per min, respectively. The change with ADH is not significantly different from the time controls of Fig. 1.

in $\mathrm{V}_{\mathrm{T}}$ produced by these agents $(r=-0.24$ and 0.44 , respectively; NS). However, both the increase in $\mathrm{HCO}_{3}^{-}$secretion produced by CAMP and that produced by isoproterenol were significantly correlated with the respective baseline $\mathrm{HCO}_{3}^{-}$ secretory rates $(r=0.98, P<0.01$ for cAMP; $r=0.80, P$ $<0.01$ for isoproterenol).

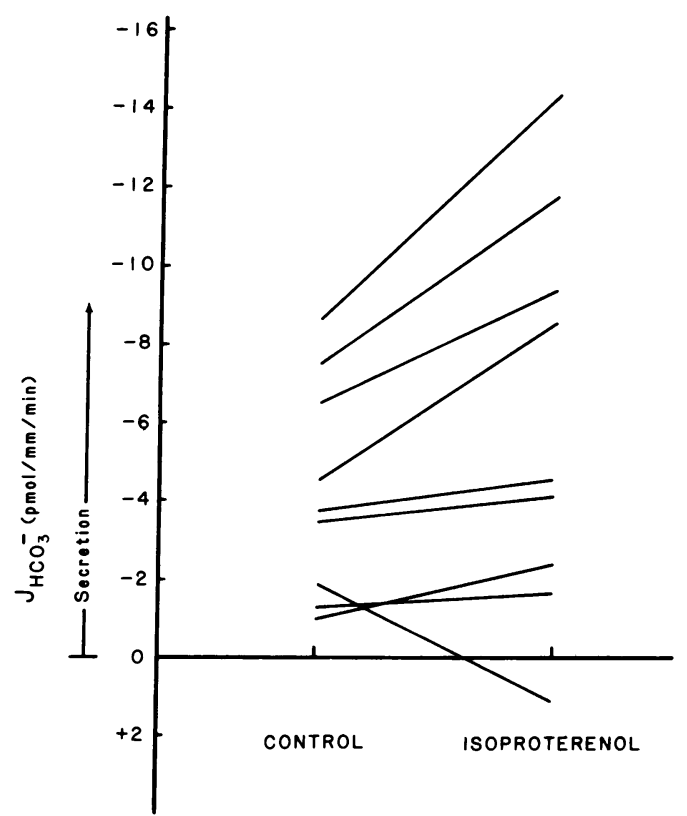

Figure 4. Effect of bath isoproterenol $\left(10^{-6} \mathrm{M}\right)$ on $\mathrm{HCO}_{3}^{-}$secretion. Conditions as per Fig. 1. Mean $\mathrm{HCO}_{3}^{-}$secretory rates for the control and isoproterenol periods are $-4.28 \pm 0.91$ and $-6.18 \pm 1.71 \mathrm{pmol} / \mathrm{mm}$ per min, respectively. The increase in $\mathrm{HCO}_{3}^{-}$secretion is significantly different from time controls in Fig. $1(P<0.001)$.
Stimulation of $\mathrm{HCO}_{3}^{-}$secretion vs. inhibition of $\mathrm{H}^{+}$secretion. In $\mathrm{HCO}_{3}^{-}$-secreting tubules, it is possible that both $\mathrm{HCO}_{3}^{-}$ secretion and $\mathrm{H}^{+}$secretion may occur simultaneously, with flux rates for $\mathrm{HCO}_{3}^{-}$secretion exceeding those of $\mathrm{H}^{+}$secretion (excluding differential leak components). If this were the case, cAMP could stimulate net $\mathrm{HCO}_{3}^{-}$secretion by inhibiting $\mathrm{H}^{+}$ secretion, by stimulating $\mathrm{HCO}_{3}^{-}$secretion, or both. In the following experiments, we addressed these possibilities, using basolateral addition of the disulfonic stilbene DIDS. The perfusate and bath solutions were the same as in the previous studies.

The effect of basolateral DIDS on $\mathrm{H}^{+}$secretion was examined in tubules dissected from $\mathrm{NH}_{4} \mathrm{Cl}$-loaded, starved rabbits (Fig. 5). These tubules exhibited baseline net reabsorption of $\mathrm{HCO}_{3}^{-}$that was reduced to zero after addition of bath DIDS; i.e., $\mathrm{H}^{+}$secretion was completely inhibited (paired $\Delta$ $=-3.70 \pm 1.16 \mathrm{pmol} / \mathrm{mm}$ per $\min , P<0.05 ;$ post-DIDS $=-1.69 \pm 1.92 \mathrm{SD} \mathrm{pmol} / \mathrm{mm}$ per min, NS from zero). $\mathrm{V}_{\mathrm{T}}$ did not significantly change with DIDS (paired $\Delta=-1.0 \pm 1.9 \mathrm{mV}$, NS). These results are consistent with the known effects of basolateral disulfonic stilbenes on acidification in the turtle bladder (13), medullary collecting tubule (14), and cortical collecting tubule (15), and demonstrate that bath DIDS was a potent inhibitor of $\mathrm{H}^{+}$secretion in our system. In time controls from acid-loaded, starved rabbits ( $n=4$, not shown), the $\mathrm{HCO}_{3}$ reabsorptive rate did not change (1.94 \pm 1.32 period $1,1.45 \pm 1.63$ period 2, $\Delta=\mathrm{NS}$ ). As shown in Fig. 5, cAMP addition to acidifying tubules produced a small fall in net $\mathrm{HCO}_{3}^{-}$reabsorption (paired $\Delta=-1.24 \pm 0.42 \mathrm{pmol} / \mathrm{mm}$ per $\min , P<0.05$ ), but, unlike DIDS, left a sizeable rate of acidification intact (post-cAMP $=2.40 \pm 0.88 \mathrm{SD} \mathrm{pmol} / \mathrm{mm}$ per $\mathrm{min}, P<0.01$ compared with zero).

If $\mathrm{HCO}_{3}^{-}$-secreting tubules from $\mathrm{NaHCO}_{3}$-loaded rabbits have a significant degree of $\mathrm{H}^{+}$secretion occurring simultaneously with $\mathrm{HCO}_{3}^{-}$secretion, complete inhibition of $\mathrm{H}^{+}$ secretion by bath DIDS would be expected to increase the net

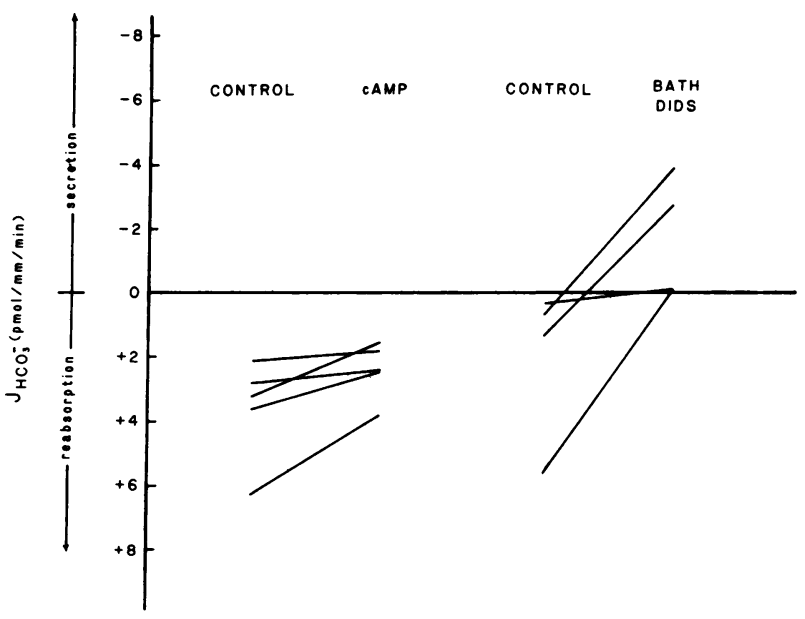

Figure 5. Effect of 8-bromo-cAMP (cAMP) $(0.1 \mathrm{mM})$ (left) and bath DIDS $(0.1 \mathrm{mM})$ (right) on $\mathrm{HCO}_{3}^{-}$reabsorption in tubules from $\mathrm{NH}_{4} \mathrm{Cl}$-loaded, starved rabbits. Mean $\mathrm{HCO}_{3}^{-}$fluxes for control and experimental periods are the following: (left) $3.63 \pm 0.72$ and $2.40 \pm 0.39 \mathrm{pmol} / \mathrm{mm}$ per min, respectively, and (right) $2.02 \pm 1.25$ and $-1.69 \pm 0.96 \mathrm{pmol} / \mathrm{mm}$ per $\mathrm{min}$, respectively. The post-DIDS values are not significantly different from zero; the post-cAMP values are significantly different from zero. 
$\mathrm{HCO}_{3}^{-}$secretory rate. As shown in Fig. 6, addition of bath DIDS to $\mathrm{HCO}_{3}^{-}$-secreting tubules had no significant effect on net $\mathrm{HCO}_{3}^{-}$secretion (paired $\Delta=+1.62 \pm 0.71 \mathrm{pmol} / \mathrm{mm}$ per min, NS to time controls), indicating minimal $\mathrm{H}^{+}$secretion in these tubules. Together, the results shown in Figs. 5 and 6 make it extremely unlikely that cAMP stimulates $\mathrm{HCO}_{3}^{-}$ secretion (Fig. 2) by inhibiting $\mathrm{H}^{+}$secretion.

Possible $\mathrm{Cl}^{-}-\mathrm{HCO}_{3}^{-}$exchange. Because cAMP increased net $\mathrm{HCO}_{3}^{-}$secretion and made the lumen voltage more positive, cAMP-induced electrogenic $\mathrm{HCO}_{3}^{-}$secretion appeared unlikely. Therefore, we considered the possibility of an electroneutral process, i.e., $\mathrm{Cl}^{-}-\mathrm{HCO}_{3}^{-}$exchange. Fig. 7 shows the effects of replacing luminal $\mathrm{Cl}$ with gluconate (solution $\mathrm{E}$ ) on cAMPstimulated $\mathrm{HCO}_{3}^{-}$secretion. It is evident that $\mathrm{Cl}$ removal reversibly eliminated $\mathrm{HCO}_{3}^{-}$secretion, consistent with $\mathrm{Cl}^{-}$. $\mathrm{HCO}_{3}^{-}$exchange (paired $\Delta=+13.11 \pm 3.12 \mathrm{pmol} / \mathrm{mm}$ per min, $P<0.02$ ). Although luminal $\mathrm{Cl}^{-}$removal tended to make $\mathrm{V}_{\mathrm{T}}$ more lumen-negative, this change was not statistically significant $(\mathrm{Cl}$ present: $-2.0 \pm 11.0 \mathrm{mV} ; 0 \mathrm{Cl}:-27.2 \pm 12.2 \mathrm{mV}$; paired $\Delta$ $=-25.2 \pm 11.3 \mathrm{mV}, \mathrm{NS}$ ).

Results using the $\mathrm{Cl}^{-}-\mathrm{HCO}_{3}^{-}$exchange inhibitor DIDS (0.1 $\mathrm{mM}$ ) in $\mathrm{Cl}$-containing (solution A) perfusate are shown in Fig. 8. First, it should be noted that the control $\mathrm{HCO}_{3}^{-}$secretory rate in the presence of luminal DIDS $(-6.65 \pm 2.22 \mathrm{pmol} / \mathrm{mm}$ per min) was not significantly different from control period values pooled from other groups. Therefore, luminal DIDS did not inhibit non-cAMP-stimulated $\mathrm{HCO}_{3}^{-}$secretion. Moreover, cAMP still stimulated $\mathrm{HCO}_{3}^{-}$secretion in the presence of luminal DIDS (paired $\Delta=-2.63 \pm 1.61 \mathrm{pmol} / \mathrm{mm}$ per min, $P<0.01$ to time controls, NS to cAMP group).

Role of basolateral $\mathrm{Na}^{+}-\mathrm{H}^{+}$exchange in $\mathrm{HCO}_{3}^{-}$secretion. Net cell-to-lumen $\mathrm{HCO}_{3}^{-}$secretion must involve disposal of a $\mathrm{H}^{+}$across the basolateral membrane or movement of $\mathrm{HCO}_{3}^{-}$ into the cell across this membrane. Proton extrusion might result from primary active transport $\left(\mathrm{H}^{+}\right.$ATPase) or secondary active transport, e.g., $\mathrm{Na}^{+}-\mathrm{H}^{+}$exchange. The latter exchanger

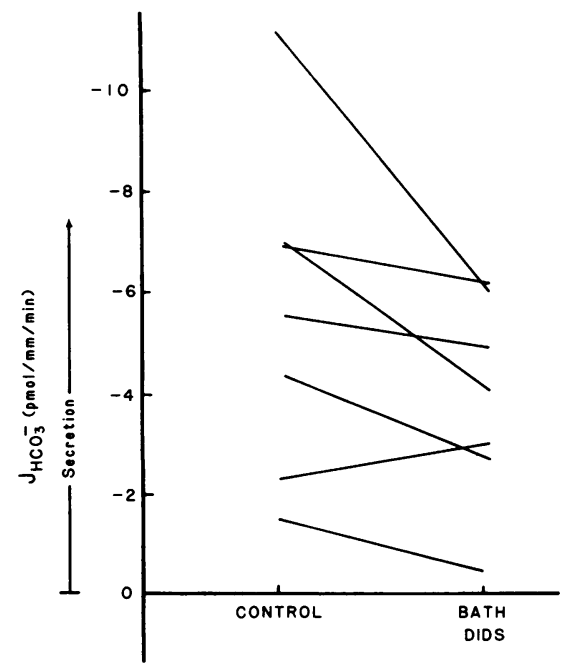

Figure 6. Effect of bath DIDS $(0.1 \mathrm{mM})$ on $\mathrm{HCO}_{3}^{-}$secretion in tubules dissected from $\mathrm{HCO}_{3}^{-}$-loaded rabbits. Mean $\mathrm{HCO}_{3}^{-}$secretory rates for control and bath DIDS periods are $-5.42 \pm 1.21$ and $-3.80 \pm 0.75 \mathrm{pmol} / \mathrm{mm}$ per min, respectively. The fall in $\mathrm{HCO}_{3}^{-}$secretion is not significantly different from that of time controls shown in Fig. 1 .

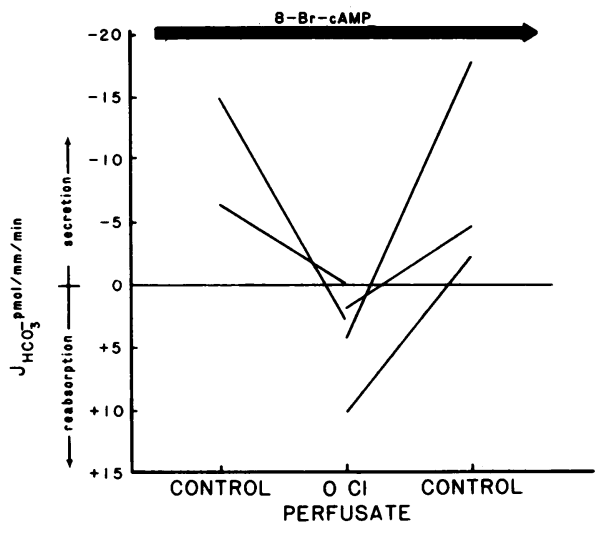

Figure 7. Effect of $\mathrm{Cl}$ removal (gluconate substitution) from the lumen on cAMP-stimulated $\mathrm{HCO}_{3}^{-}$secretion. Mean control and $\mathrm{O} \mathrm{Cl}$ $\mathrm{HCO}_{3}^{-}$secretory rates are $-9.19 \pm 3.00$ and $+3.88 \pm 1.72 \mathrm{pmol} / \mathrm{mm}$ per min, respectively. The fall in $\mathrm{HCO}_{3}^{-}$secretory rate is significant $(P$ $<0.02$ ).

has been proposed to exist at the basolateral membrane of rabbit cortical collecting tubules (16). Therefore, we attempted to inhibit cAMP-stimulated $\mathrm{HCO}_{3}^{-}$secretion by pharmacologic inhibition of the $\mathrm{Na}^{+}-\mathrm{H}^{+}$exchanger. Tubules from $\mathrm{HCO}_{3}^{-}$-loaded rabbits were perfused with solution A containing $5 \times 10^{-4} \mathrm{M}$ amiloride, and bathed in either solution B (145 $\mathrm{mM} \mathrm{Na}$ ) or solution $\mathrm{F}(5 \mathrm{mM} \mathrm{Na})$. In experiments with bath solution B ( $145 \mathrm{mM} \mathrm{Na}), 8$-bromo-cAMP $(0.1 \mathrm{mM})$ was added to the bath after $V_{\mathrm{T}}$ had stabilized. cAMP increased the lumen positivity in each tubule (pre-cAMP: $+15.8 \pm 7.5 \mathrm{mV}$; postcAMP: $+30.2 \pm 7.1 \mathrm{mV}, \Delta=+14.4 \pm 2.0, P<0.001, n=5$ ).

After $V_{\mathrm{T}}$ had again stabilized, control collections for $J_{\mathrm{HCO}_{3}}$

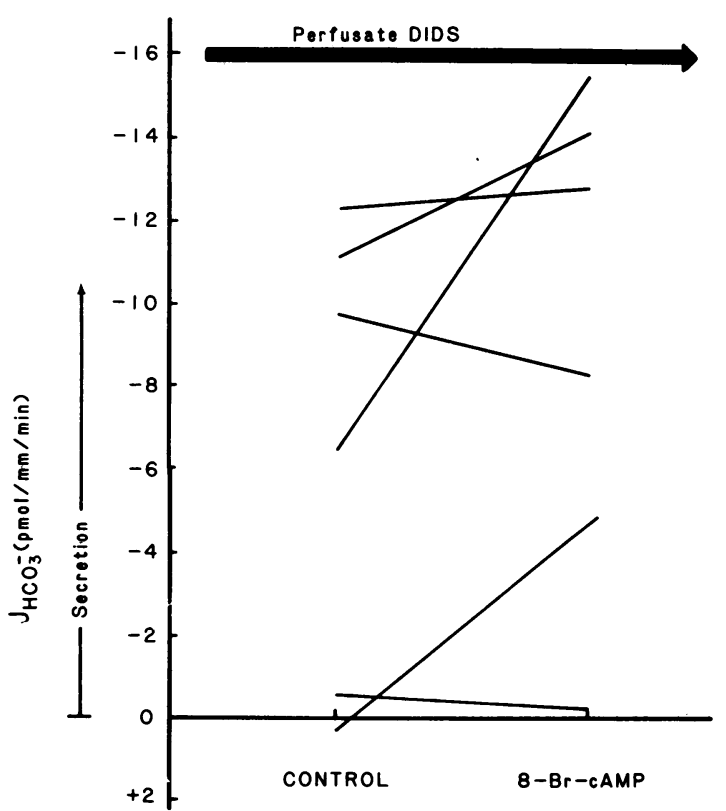

Figure 8. Control $\mathrm{HCO}_{3}^{-}$secretion and response to 8-bromo-cAMP $(0.1 \mathrm{mM})$ in tubules perfused with DIDS $(0.1 \mathrm{mM})$ in the perfusate from the start of perfusion. Mean control and post-cAMP $\mathrm{HCO}_{3}^{-}$ secretion rates are $-6.65 \pm 2.22$ and $-9.29 \pm 2.44 \mathrm{pmol} / \mathrm{mm}$ per $\mathrm{min}$, respectively. The rise in $\mathrm{HCO}_{3}^{-}$secretory rate is not significantly different from that seen with cAMP alone (Fig. 2). 
were made. When bath $\mathrm{Na}=5 \mathrm{mM}$ (solution F), bath cAMP was present from the start of perfusion. After control collections were made, $1 \mathrm{mM}$ amiloride was added to each bath, and $\mathrm{HCO}_{3}^{-}$flux was remeasured. The combination of $5 \mathrm{mM} \mathrm{Na}$ and $1 \mathrm{mM}$ amiloride should inhibit $\mathrm{Na}^{+}-\mathrm{H}^{+}$exchange by $\sim 90 \%$ (17). The results are shown in Fig. 9. Bath amiloride failed to alter $J_{\mathrm{HCO}_{3}^{-}}$in normal bath (paired $\Delta=+1.13 \pm 1.96$, $n=5$, NS) or in bath with $5 \mathrm{mM} \mathrm{Na}$ (paired $\Delta=+0.36 \pm 1.76$, $n=4$, NS).

Active vs. passive cAMP-stimulated $\mathrm{HCO}_{3}^{-}$secretion. Because both isoproterenol and cAMP depolarized $V_{T}$ to a more lumen-positive value, it is possible that the increase in collected fluid $\left[\mathrm{HCO}_{3}^{-}\right]$in response to these agents resulted simply from passive diffusion of $\mathrm{HCO}_{3}^{-}$down its electrical gradient. Indeed, as shown in Table III, comparing the collected fluid [ $\left.\mathrm{HCO}_{3}^{-}\right]$ after cAMP or isoproterenol with the $V_{T}$ (measured at the perfusion end of the pipette), using the Nernst equation, shows that these $\mathrm{HCO}_{3}^{-}$concentrations can be accounted for by the electrical driving forces. Although it is possible that slower perfusion rates would have allowed collected fluid $\left[\mathrm{HCO}_{3}^{-}\right]$to rise to values higher than those dictated by passive distribution, such slow perfusion rates are technically difficult.

Instead, we addressed this issue by measuring what we have operationally defined as the passive $\mathrm{HCO}_{3}^{-}$permeability. In these experiments, tubules were dissected from $\mathrm{HCO}_{3}^{-}$-loaded rabbits. The perfusate contained $0 \mathrm{Cl}$ and $5 \mathrm{mM} \mathrm{HCO}_{3}^{-}$ (solution $\mathrm{C}$ ), and the bath $0 \mathrm{Cl}$ and $25 \mathrm{mM} \mathrm{HCO}_{3}$ (solution D) plus $0.1 \mathrm{mM}$ DIDS. This combination of solutions should inhibit active $\mathrm{HCO}_{3}^{-}$reabsorption (DIDS) and $\mathrm{Cl}^{-}-\mathrm{HCO}_{3}^{-}$ exchange $\left(0 \mathrm{Cl}\right.$ perfusate), while providing a chemical $\mathrm{HCO}_{3}^{-}$ gradient $(20 \mathrm{mM})$ for passive diffusion from the bath into the lumen. By measuring the rise in collected fluid $\left[\mathrm{HCO}_{3}^{-}\right]$over perfused values and knowing $\mathrm{V}_{\mathrm{T}}$, a permeability coefficient for $\mathrm{HCO}_{3}^{-}$can be calculated. ${ }^{2}$ Table IV shows the results of these experiments. The control period passive $\mathrm{HCO}_{3}^{-}$permeability coefficient was $2.89 \pm 0.82 \times 10^{-6} \mathrm{~cm} / \mathrm{s}$. After 8-bromocAMP $(0.1 \mathrm{mM})$ addition to the bath, $P_{\mathrm{HCO}_{3}^{-}}$was $1.88 \pm 1.11$ $\times 10^{-6} \mathrm{~cm} / \mathrm{s}$ (paired $\Delta=-0.97 \pm 0.54 \times 10^{-6} \mathrm{~cm} / \mathrm{s}, \mathrm{NS}$ ).

\section{Discussion}

These results show that cAMP and isoproterenol stimulate net $\mathrm{HCO}_{3}^{-}$secretion in rabbit cortical collecting tubules. In contrast, $\mathrm{HCO}_{3}^{-}$secretion falls spontaneously with time or with $\mathrm{ADH}$ addition. The reason(s) for the spontaneous decline with time are unclear at present. Two possibilities seem likely, however. First, the prevailing in vivo ionic milieu may somehow regulate $\mathrm{HCO}_{3}^{-}$transport. If this is so, then the "signals" that regulated transport in vivo may have been lost in vitro when $\mathrm{PCO}_{2}$, $\left[\mathrm{HCO}_{3}\right],[\mathrm{Cl}]$, and $\mathrm{pH}$ of the bathing solutions were "clamped" at "normal" values. Second, the fall with time may be owing

2. There are several possible mechanisms for $\mathrm{HCO}_{3}^{-}$appearance in the lumen other than passive diffusion: $(a) \mathrm{CO}_{2}$ could diffuse into the lumen and become hydrated to carbonic acid, which could dissociate to $\mathrm{H}^{+}$and $\mathrm{HCO}_{3}^{-} ;(b) \mathrm{HCO}_{3}^{-}$reaching the lumen by diffusion could be titrated by $\mathrm{H}^{+}$from luminal buffers; and $(c)$ carbonic acid could diffuse into the lumen and dissociate into $\mathrm{H}^{+}$and $\mathrm{HCO}_{3}^{-}$. As discussed by Alpern et al. (18), in the absence of luminal carbonic anhydrase and non- $\mathrm{HCO}_{3}^{-}$buffers, conditions that pertain to the present experiments, the contribution of these mechanisms to luminal $\mathrm{HCO}_{3}^{-}$appearance is neglibible.

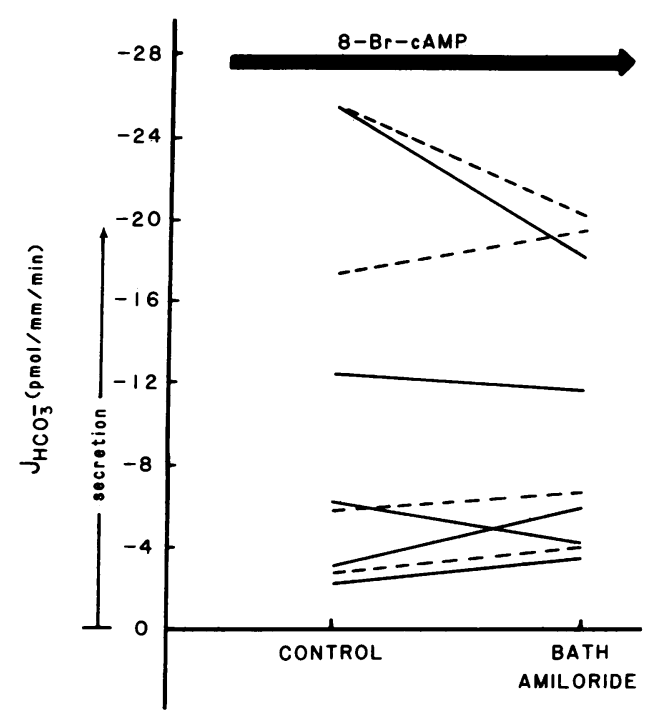

Figure 9. Effect of bath amiloride $\left(10^{-3} \mathrm{M}\right)$ on cAMP-stimulated $\mathrm{HCO}_{3}^{-}$secretion in bath containing $145 \mathrm{mM} \mathrm{Na}(-)$ or $5 \mathrm{mM} \mathrm{Na}$ (- - ) (TMA substitution). Perfusate contained amiloride $5 \times 10^{-4}$ $\mathrm{M}$ from the start of perfusion. Mean $\mathrm{HCO}_{3}^{-}$secretory rates for the control and bath amiloride periods are the following: $-9.89 \pm 4.30$ and $-8.76 \pm 2.63 \mathrm{pmol} / \mathrm{mm}$ per $\mathrm{min}$, respectively, in the $[\mathrm{Na}]=145$ $\mathrm{mM}$ group; and $-12.87 \pm 5.26$ and $-12.51 \pm 4.16 \mathrm{pmol} / \mathrm{mm}$ per $\mathrm{min}$, respectively, in the $[\mathrm{Na}]=5 \mathrm{mM}$ group. None of the changes are significant.

to the absence in vitro of regulatory hormones that were present in vivo (i.e., catecholamines). In the same way that hydraulic conductivity of cortical collecting tubules falls in vitro as the effects of in vivo $\mathrm{ADH}$ reverse, so might an in vivo catecholamine effect on $\mathrm{HCO}_{3}^{-}$transport decline in vitro. These two possibilities will require further study.

The cAMP stimulation of $\mathrm{HCO}_{3}^{-}$secretion in tubules dissected from $\mathrm{NaHCO}_{3}$-loaded rabbits appeared not to result from inhibition of $\mathrm{H}^{+}$secretion, as judged from experiments using basolateral DIDS as an inhibitor of $\mathrm{H}^{+}$secretion. We have assumed that, as in the turtle bladder (13), basolateral DIDS inhibits $\mathrm{H}^{+}$secretion but does not affect $\mathrm{HCO}_{3}^{-}$secretion, and our own data suggest that this assumption holds true for the collecting tubule. In tubules exhibiting baseline net $\mathrm{H}^{+}$ secretion ( $\mathrm{NH}_{4} \mathrm{Cl}$-loaded rabbits), addition of basolateral DIDS completely abolished acidification, whereas cAMP left intact a sizeable rate of acidification. Moreover, when basolateral DIDS was added to $\mathrm{HCO}_{3}^{-}$-secreting tubules from $\mathrm{NaHCO}_{3}$-loaded rabbits, it failed to reverse the time-dependent fall in $\mathrm{HCO}_{3}^{-}$ secretion, indicating that there was a minimal $\mathrm{H}^{+}$secretory flux in $\mathrm{HCO}_{3}^{-}$-secreting tubules. If complete inhibition of acidification by DIDS failed to stimulate net $\mathrm{HCO}_{3}^{-}$secretion in tubules from $\mathrm{NaHCO}_{3}$-loaded rabbits (Fig. 6), then cAMP could not have stimulated net $\mathrm{HCO}_{3}^{-}$secretion (Fig. 2) solely by inhibiting $\mathrm{H}^{+}$secretion in these tubules. Therefore, cAMP must have stimulated $\mathrm{HCO}_{3}^{-}$secretion directly. This conclusion is also supported by the significant correlation between baseline $\mathrm{HCO}_{3}^{-}$secretory rates and the increments in $\mathrm{HCO}_{3}^{-}$secretion induced by cAMP or isoproterenol. That is, the more an individual tubule was poised toward $\mathrm{HCO}_{3}^{-}$secretion and away from $\mathrm{H}^{+}$secretion, the more responsive it was to cAMP.

Further experiments have addressed possible cellular mechanisms of cAMP-stimulated $\mathrm{HCO}_{3}^{-}$secretion, i.e., $\mathrm{HCO}_{3}^{-}$ movement across the apical membrane and $\mathrm{H}^{+}$extrusion 
Table III. Equilibrium Values of $\mathrm{HCO}_{3}$ Versus $V_{T}$

\begin{tabular}{|c|c|c|c|c|c|c|}
\hline & \multicolumn{3}{|l|}{ Control } & \multicolumn{3}{|l|}{ Experimental } \\
\hline & $\mathbf{V}_{\mathbf{T}}$ & $E_{\mathrm{HCO}}$ & $\mathrm{V}_{\mathrm{T}}-E_{\mathrm{HCOS}}$ & $\mathbf{V}_{\mathbf{T}}$ & $E_{\mathrm{HCOS}}$ & $\mathrm{V}_{\mathrm{T}}-E_{\mathrm{HCOS}}$ \\
\hline $\operatorname{cAMP}(n=5)$ & $-21.8 \pm 4.8$ & $+1.9 \pm 0.8$ & $-19.8 \pm 5.2^{*}$ & $+12.8 \pm 5.7$ & $+6.3 \pm 3.2$ & $+6.2 \pm 4.4$ \\
\hline Isoproterenol $(n=9)$ & $-24.8 \pm 5.6$ & $+1.7 \pm 0.9$ & $-26.5 \pm 5.3^{*}$ & $-3.8 \pm 5.0$ & $+3.5 \pm 1.6$ & $-7.3 \pm 5.3$ \\
\hline
\end{tabular}

All values in millivolts. ${ }^{*} \mathrm{~V}_{\mathrm{T}}-E_{\mathrm{HCO}_{3}}$ value significantly different from zero.

across the basolateral membrane. Because the cAMP effect is associated with a change in the $\mathrm{V}_{\mathrm{T}}$ toward a more lumenpositive value, cAMP-stimulated electrogenic $\mathrm{HCO}_{3}^{-}$secretion appears unlikely. Therefore, it is possible that $\mathrm{HCO}_{3}^{-}$secretion due to cAMP occurs via an electroneutral process, i.e., $\mathrm{Cl}^{-}$$\mathrm{HCO}_{3}^{-}$exchange. This possibility is supported, though certainly not proved, by our experiments in which cAMP-stimulated $\mathrm{HCO}_{3}^{-}$secretion was completely inhibited by luminal $\mathrm{Cl}^{-}$ removal. Seemingly against this mechanism are the negative results with luminal DIDS. It should be recalled, however, that Husted et al. (13) found no effect of apical disulfonic stilbenes on apparent $\mathrm{Cl}^{-}-\mathrm{HCO}_{3}^{-}$exchange in the turtle bladder, as opposed to unequivocal effects of stilbenes on basolateral $\mathrm{Cl}^{-}-\mathrm{HCO}_{3}^{-}$exchange (19). It is not clear if our negative results indicate inaccessibility of DIDS to a DIDS-sensitive site, $\mathrm{Cl}^{-}$. $\mathrm{HCO}_{3}^{-}$exchange mediated by a DIDS-insensitive protein, or absence of $\mathrm{Cl}^{-}-\mathrm{HCO}_{3}^{-}$exchange at the apical membrane. Further experiments will be required to prove that cAMPstimulated $\mathrm{HCO}_{3}^{-}$secretion occurs via apical $\mathrm{Cl}^{-}-\mathrm{HCO}_{3}^{-}$exchange. At the basolateral membrane, $\mathrm{H}^{+}$extrusion (or $\mathrm{HCO}_{3}^{-}$uptake) must occur if cell-to-lumen $\mathrm{HCO}_{3}^{-}$movement is to result in net $\mathrm{HCO}_{3}^{-}$secretion. Proton extrusion across this membrane could conceivably occur via a $\mathrm{H}^{+}$-ATPase or via $\mathrm{Na}^{+}-\mathrm{H}^{+}$exchange. Because $\mathrm{Na}^{+}-\mathrm{H}^{+}$exchange has been proposed to exist in the cortical collecting tubule (16), we tested for such a mechanism using pharmacologic inhibition of $\mathrm{Na}^{+}-\mathrm{H}^{+}$by bath amiloride. Regardless of whether bath $\left[\mathrm{Na}^{+}\right]$was $145 \mathrm{mM}$ or $5 \mathrm{mM}, 1 \mathrm{mM}$ amiloride had no effect on cAMP-stimulated $\mathrm{HCO}_{3}^{-}$secretion. Because the combination of $5 \mathrm{mM} \mathrm{Na}^{+}$and $1 \mathrm{mM}$ amiloride inhibits $\mathrm{Na}^{+}-\mathrm{H}^{+}$exchange in proximal tubule brush-border membrane vesicles by $>90 \%$ (17), the present negative results suggest that basolateral $\mathrm{Na}^{+}$$\mathrm{H}^{+}$exchange did not play a role in $\mathrm{H}^{+}$disposal behind cAMPstimulated $\mathrm{HCO}_{3}^{-}$secretion.

cAMP and isoproterenol both depolarized the $V_{T}$ toward a more lumen-positive value, a change favoring passive $\mathrm{HCO}_{3}^{-}$accumulation in the lumen down electrical gradients. We cannot be certain from the present data whether cAMP- stimulated $\mathrm{HCO}_{3}^{-}$secretion represented active transport, passive transport, or some combination of the two. When cAMP- or isoproterenol-treated tubules are considered as a group (Table III), the collected fluid $\mathrm{HCO}_{3}^{-}$concentration can be entirely accounted for by the electrochemical driving forces; i.e., $\mathrm{HCO}_{3}^{-}$secretion could be passive. On the other hand, several lines of evidence argue against purely passive $\mathrm{HCO}_{3}^{-}$transport. First, ADH, like cAMP, tended to depolarize $\mathrm{V}_{\mathrm{T}}$, but $\mathrm{ADH}$ was associated with a fall in $\mathrm{HCO}_{3}^{-}$secretion. Second, there was no correlation between the magnitude of the change in $\mathrm{V}_{\mathrm{T}}$ and that of $\mathrm{HCO}_{3}^{-}$secretion produced by cAMP or isoproterenol. Thus, changes in $\mathrm{V}_{\mathrm{T}}$ are not necessarily accompanied by changes in $\mathrm{HCO}_{3}^{-}$flux, which would be expected for passive diffusion. Others have also found $\mathrm{V}_{\mathrm{T}}$ and $\mathrm{HCO}_{3}^{-}$flux to be poorly correlated (1). Third, under conditions that we would expect to inhibit transcellular $\mathrm{HCO}_{3}^{-}$transport $\left(0^{-} \mathrm{Cl}^{-}\right.$solutions plus bath DIDS), cAMP produced no significant change in the $\mathrm{HCO}_{3}^{-}$permeability coefficient (Table IV). If we assume that cAMP effects on paracellular $\mathrm{HCO}_{3}^{-}$permeability are the same in the presence and absence of $\mathrm{Cl}^{-}$and bath DIDS, then the $\mathrm{HCO}_{3}^{-}$permeability measured in $0 \mathrm{Cl}^{-}$solutions and with bath DIDS can be compared with that permeability that would be theoretically required to yield, via passive diffusion, the cAMPand isoproterenol-stimulated $\mathrm{HCO}_{3}^{-}$fluxes measured in the presence of $\mathrm{Cl}^{-}$and without bath DIDS. Such calculations (using the Goldman-Hodgkin-Katz equation) show that a $\mathrm{HCO}_{3}^{-}$permeability of $19.1 \times 10^{-6} \mathrm{~cm} / \mathrm{s}$ would be required to account, by diffusion, for the observed $\mathrm{HCO}_{3}^{-}$secretory flux in $\mathrm{Cl}^{-}$-bathed cAMP-treated tubules, and of $37.7 \times 10^{-6} \mathrm{~cm} /$ $s$ in the isoproterenol-treated tubules. Both of these values are significantly different from the measured post-cAMP $\mathrm{HCO}_{3}^{-}$ permeability of $1.88 \pm 2.48(\mathrm{SD}) \times 10^{-6} \mathrm{~cm} / \mathrm{s}$. The major drawback of this approach is that we do not know whether possible cAMP effects on paracellular $\mathrm{HCO}_{3}^{-}$permeability would or would not be expressed in $0 \mathrm{Cl}^{-}$solutions and in the presence of bath DIDS. Further experiments involving measurements of cellular and paracellular $\mathrm{HCO}_{3}^{-}$conductance in the presence of cAMP will be required to answer this question. Even if

Table IV. Passive $\mathrm{HCO}_{3}^{-}$Permeability Coefficients

\begin{tabular}{|c|c|c|c|c|c|}
\hline & $\begin{array}{l}\text { Perfused } \\
{\left[\mathrm{HCO}_{3}^{-}\right]}\end{array}$ & $\begin{array}{l}\text { Collected } \\
{\left[\mathrm{HCO}_{3}^{-}\right]}\end{array}$ & $J_{\text {HCOS }}$ & $\mathbf{V}_{\mathbf{T}}$ & $P_{\mathrm{HCO}}$ \\
\hline & $m M$ & $m M$ & pmol/mm per min & $m V$ & $10^{-6} \mathrm{~cm} / \mathrm{s}$ \\
\hline Control $(n=5)$ & $5.1 \pm 0.3$ & $7.8 \pm 0.5$ & $-2.40 \pm 0.69$ & $+6.2 \pm 0.4$ & $2.86 \pm 0.82$ \\
\hline 8-bromo-cAMP (0.1 mM) $(n=5)$ & $5.1 \pm 0.3$ & $6.9 \pm 0.7$ & $-1.67 \pm 1.00$ & $+9.6 \pm 1.0$ & $1.88 \pm 1.11$ \\
\hline Mean paired change, cAMP vs. control & $0.0 \pm 0$ & $-0.9 \pm 0.4$ & $+0.73 \pm 0.48$ & $+3.4 \pm 1.1$ & $-0.97 \pm 0.54$ \\
\hline$P$ & NS & NS & NS & $<0.05$ & NS \\
\hline
\end{tabular}


cAMP stimulates $\mathrm{HCO}_{3}^{-}$secretion via only passive mechanisms, the present experiments, performed under Na-transporting conditions, suggest that this effect is large and potentially physiologically important.

We can only speculate on the mechanism of the depolarization of $V_{T}$ produced by cAMP. At the apical membrane, cAMP could decrease $\mathrm{Na}^{+}$conductance or increase $\mathrm{K}^{+}$conductance. Because cAMP appears to have no effect on $\mathrm{Na}^{+}$ transport $(20,21)$ and has been reported to inhibit $\mathrm{K}^{+}$secretion (21), these two mechanisms appear unlikely. cAMP could increase electrogenic $\mathrm{H}^{+}$secretion. In the absence of a change in transepithelial $\mathrm{H}^{+}$conductance, depolarization of $\mathrm{V}_{\mathrm{T}}$ due to a $\mathrm{H}^{+}$current would dictate an increase in $\mathrm{H}^{+}$secretory flux. If this mechanism pertained, one might have expected to see an increase in $\mathrm{HCO}_{3}^{-}$reabsorption upon addition of cAMP to acidifying tubules. This was not observed (Fig. 5), though admittedly an accompanying cAMP-stimulated electroneutral $\mathrm{HCO}_{3}^{-}$secretion could have obliterated the signal. Measurements of equivalent reverse short circuit current before and after cAMP should help address this possibility. At the basolateral membrane, large conductances for $\mathrm{K}^{+}$and $\mathrm{Cl}^{-}$have been described $(22,23)$. Either a decrease in $\mathrm{K}^{+}$conductance or an increase in $\mathrm{Cl}^{-}$conductance at this membrane would move the basolateral membrane voltage away from $E_{\mathrm{K}}$ and toward $E_{\mathrm{Cl}}$ (i.e., less negative). In the absence of changes in apical membrane voltage, such a change would depolarize $V_{T}$. Because the basolateral $\mathrm{Cl}$ conductance appears to be highly variable (23), and because cAMP increases $\mathrm{Cl}$ conductances in a number of epithelia (24-27), it is possible that cAMP increases basolateral $\mathrm{Cl}$ conductance in this epithelium. Such an effect might enhance apical $\mathrm{Cl}^{-}-\mathrm{HCO}_{3}^{-}$exchange by favoring conductive cell $\mathrm{Cl}$ exit at the basolateral membrane. This possibility must also be directly examined. Such a scheme does not exclude direct cAMP effects on a $\mathrm{Cl}^{-}-\mathrm{HCO}_{3}^{-}$exchanger.

The present results can be compared with those in the turtle bladder, in which cAMP has been reported to inhibit $\mathrm{H}^{+}$secretion (28), stimulate $\mathrm{H}^{+}$secretion (29), increase passive $\mathrm{HCO}_{3}^{-}$permeability (30), and stimulate electrogenic $\mathrm{HCO}_{3}^{-}$ secretion (31). Although we cannot rule out a small inhibition of $\mathrm{H}^{+}$secretion in the cortical collecting tubule by cAMP, such an effect by itself cannot account for the changes in $\mathrm{HCO}_{3}^{-}$secretion. cAMP certainly does not stimulate $\mathrm{H}^{+}$secretion alone, nor does it appear to stimulate electrogenic $\mathrm{HCO}_{3}^{-}$secretion. As previously discussed, we cannot rule out an effect of cAMP on passive $\mathrm{HCO}_{3}^{-}$permeability in $\mathrm{Cl}^{-}$containing solutions.

A very important result of our studies is that isoproterenol, but not $\mathrm{ADH}$, mimicked the cAMP effect on $\mathrm{HCO}_{3}^{-}$secretion. Both isoproterenol and ADH stimulate adenylate cyclase in this epithelium (10). However, whereas ADH stimulates osmotic water flow (32), isoproterenol does not (33); and whereas isoproterenol inhibits $\mathrm{K}^{+}$secretion, $\mathrm{ADH}$ does not (21). In addition, Tago et al. have recently reported that isoproterenol and cAMP stimulate lumen-to-bath ${ }^{36} \mathrm{Cl}$ movement, whereas ADH does not (34). All of these studies strongly suggest the existence of either separate pools of hormone-sensitive adenylate cyclase/cAMP in the same collecting tubule cell and/or cellular heterogeneity in the distribution of hormone-linked adenylate cyclase. The latter possibility seems particularly likely, given the existence of at least two cell types (principal and intercalated) in this nephron segment (35). Because intercalated cells contain abundant carbonic anhydrase (36), it seems likely that isopro- terenol-stimulated $\mathrm{HCO}_{3}^{-}$secretion, and perhaps $\mathrm{Cl}$ reabsorption by $\mathrm{Cl}^{-}-\mathrm{HCO}_{3}^{-}$exchange $(33,34)$, are accomplished by intercalated cells. Proof of this hypothesis will require combined morphological and functional studies.

Finally, the present results are relevant to the pathophysiology of volume-contraction, $\mathrm{Cl}$-depleted metabolic alkalosis. It has been known for some time that $\mathrm{Cl}^{-}$is critical to the correction of volume-contraction metabolic alkalosis (37). Volume contraction clearly stimulates renal efferent nerve activity (38), and cortical collecting tubules appear to receive innervation and to possess $\beta$-adrenergic receptors $(39,40)$. Therefore, cortical collecting tubules under volume-contracted conditions in vivo might be expected to correspond to our in vitro tubules treated with isoproterenol. In vivo studies have shown that, under volume-contracted conditions, provision of $\mathrm{Cl}$ alone without concomitant volume expansion increases urinary $\mathrm{Cl}$ concentration and allows correction of metabolic alkalosis (41). Although this phenomenon has previously been attributed to alterations of plasma renin and aldosterone levels (41), the present studies (Fig. 7) suggest that a rise above very low levels in luminal $\left[\mathrm{Cl}^{-}\right]$could allow the $\beta$-adrenergicstimulated cortical collecting tubule to secrete $\mathrm{HCO}_{3}^{-}$, and thus contribute to correction of metabolic alkalosis. That renal nerves may play a role in this process is further suggested by the rapidity with which $\mathrm{Cl}^{-}$administration (and volume expansion) can repair metabolic alkalosis despite glomerular filtration rate being held constant (42). A reduction in adrenergic-stimulated collecting tubule $\mathrm{HCO}_{3}^{-}$secretion may also conceivably play a role in the lower urine $\mathrm{PCO}_{2}$ concentrations observed in acutely volume-expanded animals (43).

\section{Acknowledgments}

I thank Drs. John Stokes, Michael Welsh, and Russell Husted for numerous fruitful discussions and for careful critique of the manuscript, and Ms. Syd Harned for expert secretarial assistance.

This work was supported, in part, by grants from the American Heart Association (lowa Affiliate), the Veterans Administration, National Institutes of Health grants 1-K08-AM01343-01 and AM 25231, and Program Project grant HL 14388.

\section{References}

1. McKinney, T. D., and M. B. Burg. 1978. Bicarbonate secretion by rabbit cortical collecting tubules in vitro. J. Clin. Invest. 61:14211427.

2. Lombard, W. D., J. P. Kokko, and H. R. Jacobson. 1983. Bicarbonate transport in cortical and outer medullary collecting tubules. Am. J. Physiol. 244:F289-F296.

3. Laski, M. E., D. G. Warnock, and F. C. Rector. 1983. Effects of chloride gradients on total $\mathrm{CO}_{2}$ flux in the rabbit cortical collecting tubule. Am. J. Physiol. 244:F112-F121.

4. Atkins, J. L., and M. B. Burg. 1983. Secretion and absorption of bicarbonate by rat collecting ducts. Clin. Res. 31:423a. (Abstr.)

5. Knepper, M., D. Good, J. Garcia-Austt, and M. B. Burg. 1984. Deoxycorticosterone-stimulated bicarbonate secretion in cortical collecting ducts from rabbits and rats. Kidney Int. 25:278. (Abstr.)

6. Knepper, M., J. Garcia-Ausst, D. Good, and M. B. Burg. 1984. Oral ammonium chloride administration reverses deoxycorticosterone stimulation of bicarbonate secretion in cortical collecting tubules of rabbits and rats. Proc. Int. Congr. Nephrol. 9:383a. (Abstr.)

7. Woodruff, C. R., and F. G. Carpenter. 1973. Actions of catecholamines and physostigmine on cat parotid salivary secretion. Am. J. Physiol. 225:1449-1453. 
8. Gunter-Smith, P. J., and J. F. White. 1979. Response of Amphiuma small intestine to theophylline: effect on bicarbonate secretion. Am. J. Physiol. 236:E775-E783.

9. Saito, Y., and E. M. Wright. 1983. Bicarbonate transport across the frog choroid plexus and its control by cyclic nucleotides. J. Physiol. (Lond.). 336:635-648.

10. Morel, F., M. Imbert-Teboul, and D. Chabardes. 1981. Distribution of hormone-dependent adenylate cyclase in the nephron and its physiological significance. Annu. Rev. Physiol. 43:569-581.

11. Schuster, V. L., J. P. Kokko, and H. R. Jacobson. 1984 Interactions of lysyl-bradykinin and antidiuretic hormone in the rabbit cortical collecting tubule. J. Clin. Invest. 73:1659-1667.

12. Schultz, S. G. 1980. Basic Principles of Membrane Transport. Cambrdige University Press, New York. 144 pp.

13. Husted, R. F., L. H. Cohen, and P. R. Steinmetz. 1979. Pathways for bicarbonate transfer across the serosal membrane of turtle urinary bladder: studies with a disulfonic stilbene. J. Membr. Biol. 47:27-37.

14. Stone, D. K., D. W. Seldin, J. P. Kokko, and H. R. Jacobson. 1983. Anion dependence of medullary collecting duct acidification. $J$. Clin. Invest. 71:1505-1508.

15. Koeppen, B. M., and S. I. Helman. 1982. Acidification of luminal fluid by the rabbit cortical collecting tubule perfused in vitro. Am. J. Physiol. 242:F521-F531.

16. Chaillet, J. R., and W. F. Boron. 1984. Basolateral Na-H exchange in the rabbit cortical collecting tubule. Fed. Proc. 43:1089. (Abstr.)

17. Kinsella, J. L., and P. S. Aronson. 1981. Amiloride inhibition of the $\mathrm{Na}^{+}-\mathrm{H}^{+}$exchanger in renal microvillus membrane vesicles. $\mathrm{Am}$. J. Physiol. 241:F374-F379.

18. Alpern, R. J., M. G. Cogan, and F. C. Rector, Jr. 1982. Effect of luminal bicarbonate concentration on proximal acidification in the rat. Am. J. Physiol. 243:F53-F59.

19. Cohen, L. H., A. Mueller, and P. R. Steinmetz. 1978. Inhibition of the bicarbonate exit step in urinary acidification by a disulfonic stilbene. J. Clin. Invest. 61:981-986.

20. Schuster, V. L. 1985. Bradykinin and vasopressin actions on rabbit cortical collecting tubule: mechanism of their interaction and effects on Na transport. Fed. Proc. 44:1015. (Abstr.)

21. Kimmel, P. K., and S. Goldfarb. 1984. Effects of isoproterenol on potassium secretion by the cortical collecting tubule. Am. J. Physiol. 246:F804-F810.

22. Koeppen, B. M., B. A. Biagi, and G. H. Giebisch. 1983 Intracellular microelectrode characterization of the rabbit cortical collecting tubule. Am. J. Physiol. 244:F35-F47.

23. Sansom, S. C., E. J. Weinman, and R. G. O'Neil. 1984. Microelectrode assessment of chloride-conductive properties of cortical collecting duct. Am. J. Physiol. 247:F291-F302.

24. Petersen, K.-U., and L. Reuss. 1983. Cyclic AMP-induced chloride permeability in the apical membrane of Necturus gallbladder epithelium. J. Gen. Physiol. 81:705-729.

25. Nagel, W., and P. Reinach. 1980. Mechanism of stimulation by epinephrine of active transepithelial $\mathrm{Cl}$ transport in isolated frog cornea. J. Membr. Biol. 56:73-79.
26. Schlatter, E., and R. Greger. 1984. Mechanism of cAMPstimulation of active $\mathrm{NaCl}$ reabsorption in the isolated perfused medullary thick ascending limb of Henle's loop. Pfluegers Arch. 400(Suppl.):R22. (Abstr.)

27. Welsh, M. J., P. L. Smith, and R. A. Frizzell. 1982. Chloride secretion by canine tracheal epithelium. II. The cellular electrical potential profile. J. Membr. Biol. 70:227-238.

28. Lief, P. D., B. F. Mutz, and N. Bank. 1979. Effect of cyclic AMP on hydrogen ion secretion by turtle urinary bladder. Kidney Int. 16:103-112.

29. Spar, B., E. Kelepouris, R. Garrick, M. M. Civan, and Z. S. Agus. 1984. The effect of cAMP on acidification in the turtle bladder. Clin. Res. 23:239a. (Abstr.)

30. Sabatini, S. 1985. Effect of cyclic AMP on acidification in the isolated turtle bladder. Kidney Int. 27:25-30.

31. Satake, N., J. H. Durham, G. Ehrenspeck, and W. A. Brodsky. 1983. Active electrogenic mechanisms for alkali and acid transport in turtle bladders. Am. J. Physiol. 244:C259-C269.

32. Grantham, J. J., and J. Orloff. 1968. Effect of prostaglandin $E_{1}$ on the permeability response of the isolated collecting tubule to vasopressin, adenosine $3^{\prime}, 5^{\prime}$-monophosphate, and theophylline. J. Clin. Invest. 47:1154-1161.

33. lino, Y., J. L. Troy, and B. M. Brenner. 1981. Effects of catecholamines on electrolyte transport in cortical collecting tubule. $J$. Membr. Biol. 61:67-73.

34. Tago, K., V. L. Schuster, and J. B. Stokes. 1985. Hormonal regulation of chloride transport in the cortical collecting tubule. Kidney Int. 27:321. (Abstr.)

35. LeFurgey, A., and C. C. Tisher. 1979. Morphology of the rabbit collecting duct. Am. J. Anat. 155:111-123.

36. Dobyan, D. C., and R. E. Bulger. 1982. Renal carbonic anhydrase. Am. J. Physiol. 243:F311-F324.

37. Kassirer, J. P., P. M. Berkman, D. R. Lawrenz, and W. B. Schwartz. 1965. The critical role of chloride in the correction of hypokalemic alkalosis in man. Am. J. Med. 38:172-189.

38. DiBona, G. F. 1982. The function of the renal nerves. Rev. Physiol. Biochem. Pharmacol. 94:75-181.

39. Barajas, L., K. Powers, and P. Wang. 1984. Innervation of the renal cortical tubules: a quantitative study. Am. J. Physiol. 247:F50F60.

40. Munzel, P. A., D. P. Healy, and P. A. Insel. 1984. Autoradiographic localization of $\beta$-adrenergic receptors in rat kidney slices using ${ }^{[25}$ I] iodocyano pindolol. Am. J. Physiol. 246:F240-F245.

41. Galla, J. H., D. N. Bouduris, and R. G. Luke. 1983. Correction of acute chloride depletion alkalosis in the rat without volume expansion. Am. J. Physiol. 244:F217-F221.

42. Cohen, J. J. 1970. Selective $\mathrm{Cl}$ retention in repair of metabolic alkalosis without increasing filtered load. Am. J. Physiol. 218:165-170.

43. Tam, S. C., M. B. Goldstein, B. J. Stinebaugh, C. B. Chen, A. Gougoux, and M. L. Halperin. 1981. Studies on the regulation of hydrogen ion secretion in the collecting duct in vivo: evaluation of factors that influence the urine minus blood $\mathrm{PCO}_{2}$ difference. Kidney Int. 20:636-642. 